\title{
Training for performance appraisal
}

\author{
Karl B. Hofmeyr
}

The article discusses some of the typical problems associated with the successful implementation of performance appraisal. The problem of inadequate training of managers in how to deal with the face-to-face aspect of performance appraisal is highlighted. A relatively new approach to training in interpersonal skills, namely behaviour modelling, is described. This applied learning approach is aimed initially at changing behaviour rather than attitudes, with the intention that attitudes will later change to fall in line with the new behaviour. A particular performance appraisal system is briefly described and it is then shown how the four phases of behaviour modelling, i.e. key behaviours, modelling, role-playing and transfer of training, may be used to train managers how to appraise performance.

S. Afr. J. Bus. Mgmt 1979, 10:101 - 106

Die artikel bespreek sommige van die tipiese probleme wat met die geslaagde implementering van prestasiewaardasie ondervind word. Die probleem van onvoldoende opleiding van bestuurders in die hantering van die mens-tot-mens aspek van prestasie-waardasie word beklemtoon. 'n Relatief nuwe benadering tot opleiding in interpersoonlike vaardighede, te wete gedragsmodellering, word beskryf. Hierdie toegepaste leerbenadering is daarop gemik om aanvanklik gedrag eerder as houdings te verander, met die doel dat houdings later sal verander om by die nuwe gedrag aan te pas. 'n Besondere stelsel van prestasie-waardasie word kortliks beskryf, en dit word dan aangetoon hoe die vier fases van gedragsmodellering: sleuteloptredes of -stappe, modellering, rol-spel en oordrag van opleiding, gebruik kan word om bestuurders op te lei in die praktyk van prestasie-waardasie.

S.Afr. Tydskr. Bedryfsl. 1979, 10:101-106
There is little doubt that performance appraisal is one of the most misunderstood and misused (or neglected) management techniques. Any number of companies have 'gone in for' performance appraisal with considerable enthusiasm only to abandon it later, because 'we couldn't get our managers to use the system', or 'we found everyone merely paying lip service to it'. The intention of this article is to focus on a means to the successful implementation of performance appraisal.

What is performance appraisal? For the purposes of this discussion, it is sufficient to say that performance appraisal is intended to look at the person against the background of his or her work results.

There are some basic criteria for a successful system. Performance appraisal is not carried out in a vacuum, but against the background of measurable work objectives or targets previously agreed by manager and subordinate. It must be distinguished from the review of work progress which occurs as part of ongoing management control. The place of performance appraisal in a typical 'Management by Objectives' process is detailed in Fig. 1. The system should be as simple as possible, its intention being to give man and manager a common basis on which to assess the individual's strengths and weaknesses and to discuss what to do about building on the strengths and overcoming the weaknesses. However, even when all these requirements are satisfied, performance appraisal systems often fail.

Performance appraisal fails:

- when it gets bogged down with paper work, and the main emphasis seems to be the preparation of impressive looking documents for the personnel records system

- when the system becomes a 'numbers game' with elaborate scoring methods, such that the real purpose is lost. The system or forms being used for the performance appraisal should be there to provide a vehicle for communication between man and manager

- when performance appraisal is closely linked to the reward system resulting in a situation where the subordinate is not concerned with feedback he is receiving, but only wants to hear what increase he is 


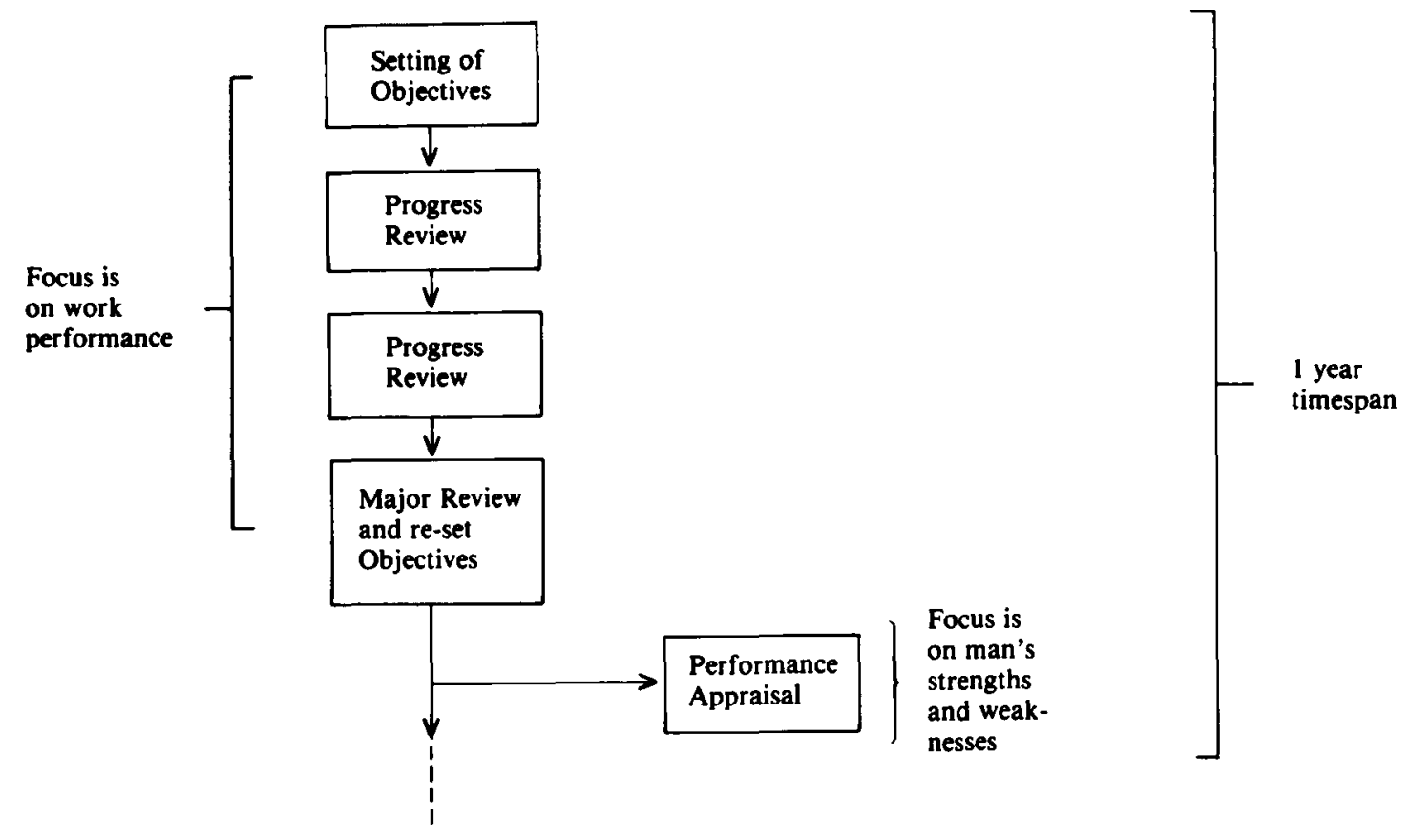

Fg. 1 Performance appraisal in relation to Management by Objectives.

getting. At the same time he feels his 'performance' in the performance appraisal is going to affect his increase and he is thus less than fully objective or candid

- when top management expects it to take place from middle management downwards, insisting that it is not really necessary at their level

- when managers who are totally autocratic for $99 \%$ of the time expect their subordinates to respond to what is, by definition, a participative system. (Similarly a company cannot expect to introduce performance appraisal successfully in an autocratic climate.)

- when the manager does not know how to carry out the face-to-face appraisal with his subordinate. He is happy to complete any appraisal forms, he understands and agrees with the concept of performance appraisal - but fears and attempts to avoid the interpersonal aspect.

The last problem is the one with which this article will be primarily concerned. How can a company go about training its managers to be able to conduct a performance appraisal meeting and make it the objective and candid, problem-solving exercise which it should be?

Many managers have gained the impression that performance appraisal requires them to 'play God' and to confront their subordinates with their lack of certain personality factors, traits and attitudes. Performance appraisal training has done little to dispel this idea.

A typical programme covers:

- how to fill in the performance appraisal form

- the importance of performance appraisal as a motivational tool

- the need for openness and candour in performance appraisal.

Managers are then given some appraisal forms and told to 'go to it'.

The problem is that the manager has not been taught how to go about actually carrying out the face-to-face ap- praisal. He has fears about how he will come across, how his subordinates will respond, and what kind of questions they will ask. He does not know how to move logically through the discussion. He has no feel for what should take place. The result is that he either avoids appraising his staff, or he appraises them in a superficial exercise, to be completed as quickly and painlessly as possible.

It should be borne in mind that performance appraisal does not have to be a soul searching, intense, psychological confrontation. As Humble ${ }^{1}$ puts it, every individual in an organization has five basic requirements:

- Tell me what you expect of me

- Give me an opportunity to perform

- Let me know how I am getting on

- Train and guide me

- Reward me according to my contribution.

Performance appraisal - in a pragmatic and objective way - allows the manager to discuss with a subordinate how he is getting on and to agree on plans for building on strengths and overcoming weaknesses. The emphasis of performance appraisal training therefore needs to shift from purpose and advantages (theoretical background) to how to carry out the process (practical application).

In an attempt to make the training more practical some companies have made use of role-plays and this has certainly been a step in the right direction. Unfortunately role-playing, while interesting and entertaining, is often unstructured and the participants may pick up some tips on the 'do's' and 'dont's', but are not left with a clear model of exactly how to lead and manage the performance appraisal interview.

A new approach to training for performance appraisal can overcome these problems. This is the use of behaviour modelling as a training method. Behaviour modelling is based on Skinnerian ${ }^{2}$ principles and has been used with considerable success in interpersonal skills training, assertiveness training and sales training.

The purpose of most training is to change behaviour. 
Because all behaviour is determined, to some extent at least, by attitudes - much training has traditionally aimed at changing attitudes in the hope that this will lead to a change in behaviour. Numerous training courses, either directly or indirectly, are saying, 'you really ought to change your attitude towards...'. The problem is, however, that attitudes are formed over a long period of time and tend to be deeply ingrained, and trainers have had little success in changing attitudes by these direct methods. And even if there were a change in attitude, the manager might well not know what new behaviour should go with the changed attitude.

Goldstein and Sorcher ${ }^{3}$ confronted the lack of success experienced by the traditional approach. What struck them was that training in technical skills, unlike training in people skills, has over the years been very satisfactory. The steps generally followed in technical skills training are:

- tell

- show

- try out

- practise.

In essence what Goldstein and Sorcher did was to apply this same sequence to training in people skills, thus:

- tell - trainees are given a framework of steps or key behaviours to use in handling the particular interpersonal situation. (An example will be given below.)

- show - a model role-play is done to show trainees 'how to do it'

- try out - trainees do role-plays in which they try out this particular way of handling the situation

- practise - they do more role-plays until they master the process.

The emphasis is now on changing behaviour. In a roleplay setting the trainee is given the opportunity to try out the key behaviours. With time he may experience a feeling of psychological discomfort (cognitive dissonance), because his new behaviour is not consistent with his existing attitudes. At this point he may reject the new behaviour, but more typically he finds he is experiencing success with the new behaviour and there is pressure to change his attitude to come into line with the changed behaviour. As Goldstein and Sorcher put it, 'If a person is somehow helped to behave in a way that may be inconsistent with his beliefs, and is rewarded for doing so, there is a high probability that he will change his beliefs to make them consistent with his new behaviour'. 3,p15 (Fig. 2 describes the process.)

\section{The method in practice}

To make the discussion more meaningful, it will be useful to discuss behaviour modelling within the context of a particular performance appraisal system. (The system is one currently being used by a large retailing company in South Africa.)

In this system, both manager and subordinate complete the form some days before the performance appraisal discussion. Being designed for the 'higher' levels in the organization it is relatively open-ended, as will be seen. (For 'lower' levels in the organization a more structured 'merit rating' form would be used.)

The form is divided into three sections:

- Results and skills analysis

- Areas for improvement (shown in Fig. 3)

- Plans for training and development.

Subordinate and manager come together for the performance appraisal, each having answered the questions in the spaces provided on the form. The intention is that they now move through the form discussing, first, the skills and strengths highlighted by the individual's work performance, and then, those areas where improvement can be made. Against this background they agree on training and development objectives and a plan of action to improve job performance.

In order that the performance appraisal should be a worthwhile, successful exercise, the managers are trained to appraise their employees' performance by means of behaviour modelling. Using the four steps of behaviour modelling described earlier as a framework, training for performance appraisal would take place as follows:

\section{Key behaviours}

A framework of key steps is drawn up which will guide the 'manager' through the appraisal interview. The framework is obviously designed to support the particular appraisal form being used. A framework of seven steps which could be used with the form suggested in Figure 3 would be ${ }^{4}$ :
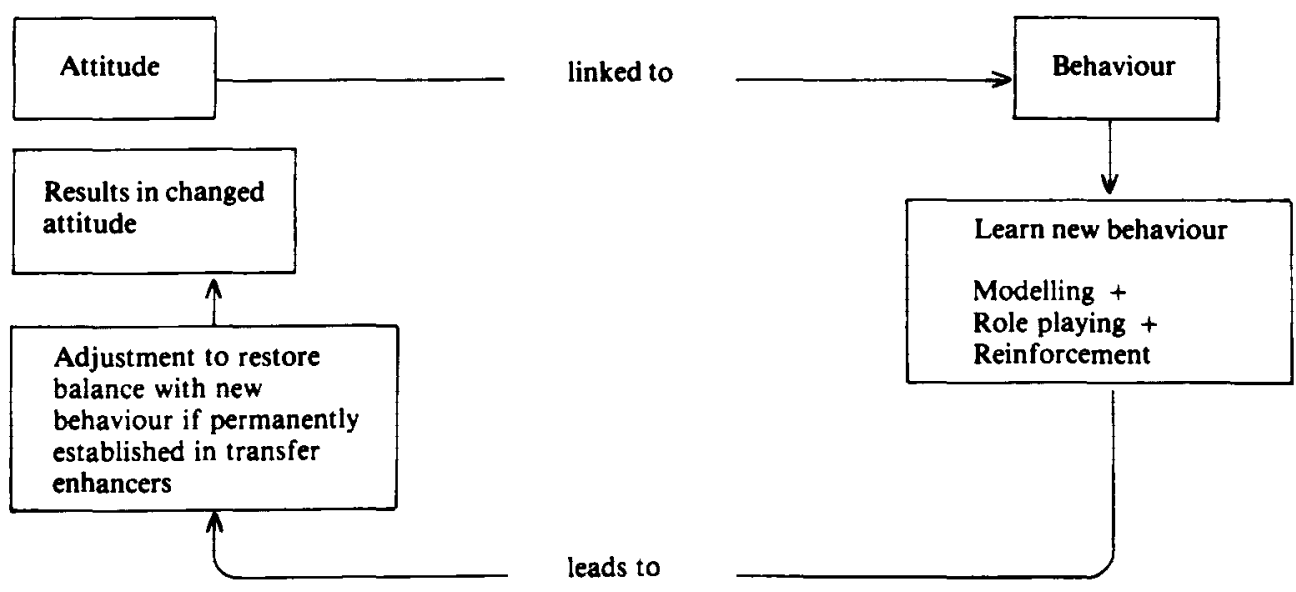


\section{AREAS FOR IMPROVEMENT}

A. Where does performance appear to have been signiflcantly below expectation? Examine (i) Objectlves, (ii) standards of performance, and (iil) any other areas of the total job.

(Consider not only results, but also the manner and methods used, i.e. were they constructive; helpful; motivating; damaging etc.?)

B. Were there any modifying conditions, obstacles or frustrations which inhibited performance in these areas and made expected results difficult to achieve?

C. In view of the above, what particular weaknesses or lack of skills are apparent?

D. In which specific areas is further development and training required to improve on-the-job performance?

II.

Fy. 3 Section B of performance appraisal form4.

- Clarify the purpose of the meeting and explain how you will conduct it.

- Ask the employee to give his assessment of performance first. Listen carefully and when necessary ask for clarification in a neutral manner.
- After each section, emphasize areas of general agreement. Raise and discuss objectively pertinent differences, plus or minus, which you have noted.

- Restate the major points arising out of the appraisal.

- Together with the employee, identify areas requiring 
personal development and/or training. Encourage him to formulate action plans/objectives to meet these needs stressing that you will assist him whenever required.

- Summarize decisions taken and agree on your plan of action.

- Assure the employee of your desire to help him in his personal progress and development.

It is worth noting in this framework that the employee, in fact, assesses his own performance first and the manager's role is to listen and then agree or disagree with, or add to, the points raised by the employee. The employee is usually a very good (if a little conservative) judge of his own performance. The manager has to disagree with the employee where necessary and to raise strengths or weaknesses overlooked, but his task is made easier by the fact that the employee assesses his own performance first.

In addition to the key behaviour for performance appraisal, a set of the key behaviours for general supervisory effectiveness may also be used. These would require the manager, for example, to:

- maintain the self esteem of the employee.

- encourage the employee to express his opinions and suggestions.

- always agree on a definite action programme.

\section{Model}

The applied learning approach requires that the potential learner be provided with a display (filmed or live) of a person (the model) performing the specific skill behaviours which the learner is then required to copy. A great deal of our learnt behaviour is derived from our imitation (or modelling) of the behaviour of other persons, in particular 'models' whom we respect and admire, hence the use of a model role-play to show trainees how the appraisal interview should take place.

The model must obviously be highly credible and must follow the framework very closely so that trainees are able to 'copy' the model when they do their role-plays. The model role-play may either be done 'live' by two instructors (who have obviously rehearsed thoroughly) or be presented on film or TV. It is worth noting that if a film or TV model shows two actors unknown to the trainees, they may be tempted to question whether their instructor (who is going to be critiqueing them) 'can do it properly himself'.

\section{Role-playing}

Trainees are now given the opportunity to practice appraisal discussions, using the framework of key behaviours and the model as their points of reference. One trainee is asked to play the manager role and another the employee role. Because the trainees cannot be expected to $a d$ lib all the content of a performance appraisal interview, each is given a 'case history' - a write-up of a fictitious set of facts and details on which they must base their roles. (An example of a manager's case history is given in Fig. 4.) The case histories have to be written to suit the company in which the training is taking place, and the performance appraisal system in use. The writer
Resident Engineer

You are Don Hamilton and you have to prepare for your performance appraisal interview with one of your supervisors, Dick Davies.

Dick was appointed as a supervisor nine months ago and has run into some problems since taking up the job. He was recruited from outside the company and 'thrown in at the deep end'. He had been a supervisor in his previous job but the work was quite different. For the first few months he had to constantly ask his artisans about systems and procedures to be followed and occasionally they took advantage of his lack of knowledge. Time-keeping of his staff, for example, has not been good.

You feel he is basically competent, but his lack of job knowledge has caused problems. Another example is that the store-keeping system has not been adhered to by himself and his staff.

You have been very busy yourself, being away from site from time to time, and have possibly not given him the necessary support and training.

His control of the quality of the work done has been thorough and you have no complaints in this area. He brought with him from his previous job an excellent system for administering the petty cash and you feel this could be installed at the other sites within the company.

$\mathrm{He}$ is experienced in interpreting blue-prints and had done this efficiently.

During the year you set him a specific objective to finish an important section of the installation in a given time period and he managed to achieve this, often working in his own time doing preparation and planning work.

Fig. 4 Example of case history for use in role-play.

may build differences of viewpoint and detail into each set of case histories - to challenge the trainees and make the role-plays as 'life-like' as possible.

Role-playing on its own is not sufficient to change behaviour. If this is to be achieved, reinforcement (positive rather than negative) for enacting the role-play behaviour must take place. In the industrial setting it has been found that 'social reinforcement' - for example praise, approval and encouragement - usually serves as the most effective reward.

The performance appraisal training being described takes place in a social setting. The role-players are enacting an appraisal interview in front of a group of their peers. The instructor manages the learning situation in such a way that the appraiser in the role-play receives reinforcement from the group. After a role-play, the instructor critiques what occurred by going through the key behaviours step by step, commenting on whether the appraiser adhered to each step, or whether any other erros occurred. These are corrected in a non-critical manner. The role-players themselves and the observing trainees are then asked for their comments. This has to be wellhandled by the instructor as the tendency, initially at least, is for the discussion to cover technical details or secondary issues, not important in the learning process. The trainer has to guide the group towards objectivity and non-emotional, non-critical reactions to the views and performances of others.

There is a temptation to use television to film and replay the 'appraisals' and while this may be entertaining, it can divert the trainees from the central learning issue did the appraiser follow the framework of key behaviours or not?

\section{Overleaming and transfer of training}

Before a trainee can feel at ease with the method and the process he must have had considerable practise in the 
role-play setting. The term 'overlearning' refers to a point where the manager has enacted the behaviour so many times that he responds automatically in terms of the newly learnt behaviour pattern. He no longet needs to refer constantly to the framework, and has the confidence to handle the performance appraisal discussion in his 'real life' work situation. For any degree of overlearning to take place the size of the training group would have to be small and they would require at least two days of intensive training.

It is in fact the 'real life' work situation which should be the main concern of the trainer. Will the trainees use what they have learnt, at the work site? Competent performance during training is no guarantee that training has been successful and many training programmes fail because transfer of iraining does not take place.

The behaviour modelling approach which has been described goes a long way towards ensuring the transfer of training. Trainees have learnt how to carry out performance appraisal; they have had the opportunity to practise the key behaviours at length and feel comfortable with the process; they have experienced the fact that it works and that its use has obvious benefits for them, and their subordinates.

If the key principles in this applied learning approach: modelling, role-playing, and social reinforcement, are well managed by the trainer there is a better chance that what the trainee learns will in fact be applied in the work situation, than has been the case with traditional training for performance appraisal.

\section{Conclusion}

The intention of this article has not been to make the reader an expert on the philosophy or detail of performance appraisal. Instead it has focussed on some of the weaknesses of traditional attempts to implement effective performance appraisal systems, especially inadequate training for performance appraisal. It has sought to introduce the reader to the concept of behaviour modelling and to show how this technique can be used as a powerful tool to train managers in appraising performance, as it is the author's contention that the introduction of effective performance appraisal in a company does not end with the design of a sound system, but rather that this is where it begins.

\section{References}

1 HUMBLE, J.W. Improving business results. McGraw-Hill, 1968, p.56.

2 SKINNER, B.F. Beyond freedom and dignity. New York, Knopf, 1971.

3 GOLDSTEIN, A.P. \& SORCHER, M. Changing supervisor behavior. Pergamon Press, 1974.

4 STAEGEMANN, V.A. As quoted in an address to the Annual General Meeting of the Education Evaluation Association of Southern Africa, 14 April 1977. 